\title{
From Chakrabarty to Chimeras: The Growing Need for Evolutionary Biology in Patent Law
}

\author{
Ryan M.T. Iwasaka
}

\section{INTRODUCTION}

In 1988, the U.S. Patent and Trademark Office (PTO) granted the first patent on a "nonnaturally occurring non-human multicellular living organism": a mouse genetically engineered to be particularly susceptible to cancer. ${ }^{2}$ Although Congress had earlier provided limited protection for certain cultivated plants, ${ }^{3}$ bioengineered animals-ranging from singlecelled bacteria to mammals and amphibians-were barred from patent protection on ethical and moral grounds. In 1980, the U.S. Supreme Court

1. The PTO uses this phrase to define patentable subject material for living creatures. See PATENT \& TRADEMARK OFFCE NOTICE: ANMMALS-PATENTABILTY, reprinted in 1077 OFFICIAL GAZETTE U.S. PAT. \& TRADEMARK OFF. 8 (Apr. 21, 1987). This term is the only formal definition that the PTO provides on the topic.

2. See U.S. Patent No. 4,736,866 (Apr. 12, 1988). For additional discussion of this patent, commonly known as the "Harvard mouse," see SHELDON KRIMSKY, BIOTECHAICS \& SOCIETY: THE RISE OF INDUSTRIAL Genetics 44-45 (1991); David Manspeizer, The Cheshire Cal, the March Hare, and the Harvard Mouse: Animal Patents Open Up a New, Genetically-Engineered Wonderland, 43 RUTGERS L. REV. 417 (1991); and Elizabeth Corcoran. A Tiny Mouse Came Forth, SCI. AM., Feb. 1989, at 73.

3. See Plant Variety Protection Act, Pub. L. No. 91-577. 84 Stat. 1542 (1970) (codified as amended at 7 U.S.C. $\$ \S 2321-2583$ (1994)); Plant Patent Act, Pub. L. No. 82-593, 66 Stat. 804 (1952) (codified as amended at 35 U.S.C. $\$ \S 161-164$ (1994)). The current debate over liveorganism patents centers primarily on genetically altered animals-in particular, multicellular animals. There remain, however, biodiversity and environmental concems over the use of patent protection to encourage the development of genetically altered plants. See, e.g., Ned Hettinger. Patenting Life: Biotechnology, Intellectual Property, and Environmental Ethics, 22 B.C. ENVTL. AFF. L. REV. 267, 268-69 (1995); Terri A. Jones, Note, Patenting Transgenic Animals: When the Cat's Away, the Mice Will Play, 17 VT. L. REv. 875, 877 (1993). 
drew upon a growing trend in the law to allow patents for "anything under the sun that is made by man," ${ }^{4}$ thereby opening the universe of patentable subject matter to living organisms. The Court, however, failed to define the boundaries of this new area of patent doctrine, choosing instead to induce the fledgling biotechnology industry to draw policymakers into the issue. But Congress and the PTO tacitly refused to address the growing concerns and let the question of animal patentability go unresolved. As a result, over 6000 biotechnology patent applications were filed, which were then held in limbo until the PTO's 1988 action. $^{5}$

The PTO's decision to grant the mouse patent was its second attempt to force Congress or the courts to end the tumultuous and confusing decadelong struggle over animal patentability. In response to the PTO's new policy, a flood of legal and political challenges flowed from numerous special interest groups that feared the detrimental moral and economic effects such patents could have on nature and society. ${ }^{6}$ In 1991, the PTO obtained partial closure on the issue when the U.S. Court of Appeals for the Federal Circuit consolidated and disposed of the legal challenges, dismissing the claims for lack of standing. ${ }^{7}$ Although the Federal Circuit failed to address any questions of morality or law effectively, its conclusion cleared the way for the PTO's declaration that bioengineered animals and plants were appropriate subject matter for patent protection, provided that they met the traditional standards set forth in 35 U.S.C. $\S 101 .^{8}$ Both the

4. Diamond v. Chakrabarty, 447 U.S. 303, 309 (1980) (quoting the 1952 congressional joint committee report reviewing the various sections of the Patent Act of 1793).

5. See Rick Weiss, How Do You Patent a New Elephant, WASH. POST, Sept. 20. 1987, at C3.

6. For discussions of the response to the PTO's decision, see generally Michael B. Landau, Multicellular Vertebrate Mammals as "Patentable Subject Matter" Under 35 U.S.C. \$ 101: Promotion of Science and the Useful Arts or an Open Invitation for Abuse?, 97 DICK. L. REv. 203 (1993); Matthew McGovern, Note, Biotechnology and the Patenting of Living Organisms, 3 ANIMAL L. 221 (1997); Carrie F. Walter, Note, Beyond the Harvard Mouse: Current Patent Practice and the Necessity of Clear Guidelines in Biotechnology Patent Law, 73 IND. L.J. 1025 (1998); Michael E. Sellers, Case Note, Patenting Nonnaturally Occurring. Man-Made Life: A Practical Look at the Economic, Environmental, and Ethical Challenges Facing "Animal Patents," 47 ARK. L. REV. 269 (1994); and Jack Miller, The Right To Engineer New Creatures, TORONTO STAR, May 30, 1987, at M3.

7. See Animal Legal Defense Fund v. Quigg, 932 F.2d 920, 922-25 (Fed. Cir. 1991). Although the Federal Circuit disposed of the case by ruling that the plaintiffs lacked standing to challenge the granting of animal patents, the Quigg court saw that it was equally necessary to settle the subject-matter question, expressing, in dicta scattered throughout the opinion, the view that animals were indeed patentable. See id.

8. The Federal Circuit's holding in Quigg created a procedural void regarding standing. It is unclear who, if anyone, could challenge the PTO's action. Because the animal-rights activists were not directly harmed by the PTO's actions, they were barred from bringing such claims. In theory, the biotechnologists benefiting from the new rules were the only people cligible for remedies under the Quigg court's analysis. One could make the argument that the animals are the parties actually harmed, but no one can claim standing on their behalf. Thus, it appears unrealistic that a valid claim will ever be brought under the Quigg regime. Although other groups opposing animal patents have tried, no challenge has procedurally gone as far as Quigg, and no attempt has come close to overturning its basic holding. 
Federal Circuit and the PTO relied heavily on the Supreme Court's earlier opinion and did little to clarify the guidelines or definitions for patentability. They merely established a case-by-case review process that gave the PTO arbitrary discretion over the factors it would consider in determining acceptable subject matter. This system, akin to the illconstructed "I know it when I see it" analysis that Justice Potter Stewart employed for pornography, ${ }^{9}$ remains the regime under which patent review for bioengineered organisms operates today. ${ }^{10}$

Despite the lack of systemic clarity, the basic question of animal and plant patentability appeared to be settled. Yet as of July 1999, the PTO faced a backlog of new applications and old appeals, due in part to the lack of established guidelines. ${ }^{11}$ Among the thousands of pending biotechnology patent applications, the PTO had received over 1900 patent applications specifically for genetically altered animals and had approved fewer than ten percent. ${ }^{12}$ And among those applications, the PTO received one highly controversial application: a request for a patent on the process by which scientists can create "chimeras," hybrid organisms that are part animal and part human. ${ }^{13}$ The PTO recently denied this request, citing the government's rigid moral ban against patents on human beings. ${ }^{14}$ But this test case reopened old wounds, exposing the lack of defined standards and the PTO's inability to address such questions within a clear and reasoned framework. ${ }^{15}$ The chimera case uncovered one important development in

9. See Jacobellis v. Ohio, 378 U.S. 184, 197 (1964) (Stewart. J., concurring).

10. See infra Section II.C.

11. See Rochelle K. Seide \& Janet M. MacLeod. Drafting Claims for Biotechnological Inventions, 585 PAT., COPYRIGHTS, \& LITERARY PROP. 381, 388 (1999) ("There are 237 unexamined applications, 92 allowed applications, 16 applications on appeal to the PTO Board of Appeals, 10 applications at the Board of Interferences and 424 applications in active prosecution.").

12. See id. at 388 n. 10 (noting that among the transgenic animals patented are 106 mice, 9 rats, 9 rabbits, 8 sheep, 8 pigs, 8 cows, 7 goats, and one each of a nematode, bird, fish. guinea pig, abalone, canine, and turkey hen). Patent applications for transgenic animals are approved at a rate slightly lower than that of most other patent categories. Although $80 \%$ of all first-time patent applications are rejected, transgenic animal patents are rejected at a 94\% rate. See Paul Recer, Patent Application Begs the Question: What Is a Human?, LEGAL INTEULGENCER, June 21. 1999 , at 4.

13. See Thomas A. Magnani, The Patentability of Human-Animal Chimeras, 14 BERKELEY TECH. LJ. 443 (1999); Eliot Marshall, Legal Fight over Patents on Life: Duo Aims To Provoke Debate over Patents Involving Human Tissue, 284 SCIENCE 2067 (1999); Recer, supra note 12; Allen Salkin, "Mad" Scientist: Ban Frankensteins, N.Y. POST, June 7, 1998, at 35. The patent applicants had not actually developed such a creature, but made the request as a test case to force the PTO to define the standards of review for transgenic animals. See Marshall, supra, at 2067. The applicants, Professors Stuart Newman and Jeremy Rifkin. are opposed to the patenting of life in general and hoped, at the very least, that their chimera application would cause policymakers to formulate a set of detailed policies that better define the process by which a live-organism-patent application is reviewed. See Salkin, supra.

14. See Marshall, supra note 13, at 2067; Recer, supra note 12.

15. See Jenna Greene, He's Not Just Monkeying Around, LEGAL TIMES. Aug. 16. 1999. at 17. The denial of the chimera patent was based, in part, on the PTO's conclusion that the organism lacked utility. This conclusion is questionable given that animals expressing human characteristics 
contemporary patent law: It revealed that the issue is no longer whether animals and plants can be patented, but which animals and plants should receive patent protection.

In light of this controversy, the government's failure to resolve the questions surrounding live-organism patents appears to have had two new effects. First, it has left some room for debate over the fundamental propriety (not legality) of permitting plant and animal patents. Opponents of such patents argue that the absence of standards underscores the complexity and tenuous nature of patenting life; consequently, they argue, the PTO should suspend its practice, at least until Congress revises the law to regulate the powerful effects that modern technology can have on the development of new plants and animals. ${ }^{16}$ Second, the lack of standards has led to confusion over which organisms qualify for patent protection. The lack of doctrinal clarity generally takes two forms: (1) patent applications refused by the PTO for unclear reasons; and (2) patents granted for organisms that would not meet even the basic legal standards of prior art and obviousness upon which the PTO and courts have always relied. ${ }^{17}$ These factors have combined to create the backlog of applications and appeals pending in the patent system.

This Note attempts to address the need for clear standards by proposing the introduction of rules and tests based on the principles of evolutionary biology. Evolutionary biology can generally be defined as the study of species' development through their interaction with the environment. It is based on Charles Darwin's theory of natural selection. ${ }^{18}$ Darwin hypothesized that life developed through a process of competition between and within species. In any given natural environment, ${ }^{19}$ species can thrive or perish, thereby allowing nature to select certain organisms for survival

make better research subjects because their test results provide a more accurate measure of the actual effects that can be expected on humans. See Recer, supra note 12. This inconsistency in the PTO's argument undermines much of its opinion.

16. For an excellent summary of these issues and concerns, see Mark O. Hatfield, From Microbe to Man, 1 ANIMAL L. 5 (1995). More radical opponents may never be satisfied with any law or regulatory regime that allows the patenting of plants and animals.

17. Nonobviousness and novelty are two basic requirements for a successful patent application. See Paul Goldstein, Copyright, Patent, Trademark \& Related State DOCTRINES: CASES \& MATERIALS ON THE LAW OF INTELleCTUAL PROPERTY 400-51 (4th ed. 1997). Anyone seeking a patent must prove that his or her invention has not already been invented (novelty) and is not merely an obvious modification of an existing product (nonobviousness). Thus, a product of nature already exists, and some modifications on a natural product may appear to be obvious developments. (1859).

18. See Charles Darwin, The Origin of SPecies (J.W. Burrow ed., Penguin Books 1985)

19. As is commonly understood, organisms that thrive in one environment may perish in another. Thus, polar bears would be selected for in the arctic but selected against in the desert. The environment in which the bioengineered organism is evaluated should be one in which its progenitors naturally occurred. To use the example again, one would not test a transgenic polar bear's survival or selection rate in a desert environment. 
and others for extinction. A single trait or a collection of traits may lead to the selection of one species over another, and, within a particular species, the mutation of a single trait may result in the creation of a new species that would supplant the existing one through a process of interbreeding. Evolutionary biology then draws upon the fields of population ecology, genetics, and predictive modeling to form an integrated methodology for describing the evolutionary history and potential of a given organism. ${ }^{20}$

Although the integration of evolutionary biology seems to be an obvious step in the development of the law of plant and animal patents, an extensive search of the legal and scientific literature reveals scant reference to anything that resembles Darwin's idea and the science it spawned." This omission is stunning. Over the last half-century, genetic technology has redefined the scope of human power over nature and the basic building blocks of life. Biotechnology has harnessed this power to "create" organisms that this world has never seen before. The introduction of new organisms into our environment inevitably changes the biological landscape. Evolution is the organized and reasoned process of such changes. Thus, the inclusion of this scientific theory should provide, in its basic form, a framework upon which we may build a mode of analysis that will shift patent law away from the ad hoc and toward the logical. Evolutionary biology offers a tested foundation where there currently is none and is, therefore, superior to the current system.

Through the application of evolutionary biology, the functional elements of natural selection and population ecology can be applied to the analysis of animal and plant patentability. Employing evolutionary biology, this Note proposes that patents be granted only on those nonnaturally occurring organisms that exist in some tangible form and that are theoretically favored due to the intervention of, and their utility to, humans. ${ }^{22}$ It argues, in essence, that patentable organisms should be defined

20. For a general discussion of the theory and its constituent pans, see Francisco J. AYALA. POPULATION AND EVOLUTIONARY GENETICS (1982); BIODIVERSTTY (E.O. Wilson ed.. 1988):

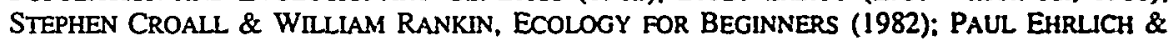
ANNE EHRLICH, EXTINCTION: THE CAUSES AND CONSEQUENCES OF THE DISAPPEARANCE OF SPECIES (1981); DOUGLAS J. FUTUYMA, EVOLUTIONARY BIOLOGY (2d ed. 1986); BILl MCKIBBEN, THE END OF NATURE (1989); JONATHAN MILLER \& BORIN VAN LOON. DARWIN FOR BEGINNERS (1982); RODERICK FRAZIER NASH. THE RIGHTS OF NATURE: A HISTORY OF ENVIRONMENTAL ETHICS (1989); and EDWARD O. WILSON, THE DIVERSITY OF LIFE (1992).

21. Perhaps the political nature of the issue, combined with its scientific complexity, leads to a confusion that welcomes the introduction of these principles, but simultancously raises anxiety about their impact on the overall patent system. Put differently, policymakers may feel unequipped to resolve the controversy because of their ignorance about the potential solutions. At least one recent commentator has observed a broad, growing discomfon with the use of science in legal inquiry. See DAVID L. FAIGMAN, LEGAL ALCHEMIY: THE USE AND MISUSE OF SCIENCE IN THE LAW 197-204 (1999). The absence of evolutionary biology from the patent literature is discussed further in Part II of this Note.

22. Utility is another fundamental requirement for a successful patent application. Patents are granted only to inventions that have some use. In the case of live-organism patents, utility to man 
as nonnaturally occurring plants and animals whose prospects for continued existence are predicated not upon their selection by nature, but upon their selection by people.

Part II of this Note recounts the development of the legal standards regarding animal and plant patents. Part III then introduces the proposal for applying evolutionary biology and discusses its utility in the patentapplication process. In particular, Part III employs the theory in order to evaluate the role that human intervention plays in the development and survival of genetically altered organisms. Part III also discusses the methods by which evolutionary biology can be injected into the existing patent-review process and weighs the advantages and disadvantages that would result from the use of these scientific principles. Part IV concludes this study by reasserting the value of evolutionary biology in addressing many of the deficiencies in the current doctrine, including those raised in the chimera controversy.

At the outset, an important caveat bears mentioning: This Note does not directly address the moral and ethical concerns that have dominated the debate over animal and plant patents. Rather, this Note offers a reform of the troubled patent-application process, notwithstanding the moral objections. The proposal assumes that the PTO will continue to issue patents on living organisms regardless of the outcome of the chimera case or the ongoing objections of the opposition. Property interests and the value to scientific inquiry appear to be such weighty incentives that the debate may never come to a complete resolution. ${ }^{23}$

Instead of becoming mired in moral and ethical controversy, this Note addresses real and immediate deficiencies in the patent-application process. These problems are systemic, requiring detailed attention that opponents and proponents of live-organism patents seem unwilling to give them at this time. In the meantime, it is this Note's contention that the PTO is erroneously issuing patents on organisms that are, or would be, the products of nature. The proposal offered here is an attempt to rectify this situation. At the very least, this Note seeks to expose the need for more rigorous scientific assessment in the process by showing that the current case-bycase patent-application evaluation, employing vague standards of review, is insufficient to deal with biotechnological developments.

is a required element as well. As will be discussed in Part III, the utility standard is used as an essential element in the assessment of the patentability of an invention. This Note proposes that patents be granted only to those organisms that exist and survive because of their utility to man.

23. Cf. Animal Legal Defense Fund v. Quigg, 710 F. Supp. 728, 730 (N.D. Cal. 1989) (discussing the growing economic importance of biotechnology in the United States and the Chakrabarty ruling's initial impact on the industry). 


\section{DeVelopment of The CurRent Patent Policy}

A review of the relevant legal literature reveals scant mention of evolutionary biology principles in the debate over animal and plant patents. The following Sections briefly reconstruct the relevant scholarly history in order to explain the reasons for the theory's exclusion and to provide justifications for its inclusion in the modern debate over the patenting of life.

\section{A. Historical Origins of the Prohibition on Plant and Animal Patents}

Patent law predates the recognized birth of evolutionary biology, tracing its origins to English common law. The first English patent statute was enacted in $1624 .{ }^{24}$ On the other hand, evolutionary biology was virtually nonexistent until 1859, when Charles Darwin first published The Origin of Species. ${ }^{25}$ Evolution is, therefore, a relatively modem scientific concept, and the fusion of genetics and evolutionary theory is an even more recent development. Thus, one could argue that the absence of evolutionary biology in patent law is simply an issue of timing: Patent law could not possibly have anticipated the innovations two centuries later in scientific theory. But the relatively recent development of evolutionary biology does not explain its continued exclusion from the legal doctrine.

Until 1930, patents on plants and animals were barred. ${ }^{26}$ This prohibition rested on three philosophical assumptions. First, patents on plants and animals would allow humans to hold exclusive rights to other living organisms, an arrangement that seemed (and continues to seem) immoral to many. ${ }^{27}$ Here the problem boils down to a very simple and fundamental tenet of intellectual property law: Patent owners have the right to control the license and use of all items listed in a patent. Thus, if someone held a patent on Dachshund dogs, any person who wished to have a Dachshund would need permission from the patent holder and would have

24. See GOLDSTEIN, supra note 17, at 382 (discussing the history of the British Statute of Monopolies).

25. DARWIN, supra note 18.

26. See O'Reilly v. Morse, 56 U.S. (15 How.) 62. 132 (1853) (holding natural principles or discoveries to be unpatentable); Ex pare Latimer, 1889 Dec. Comm'n Patent 123 (1889) (holding plants to be unpatentable). There were a few exceptions to this rule. For example. Louis Pasteur received a patent on a manufactured form of yeast in 1873. See P.J. Federico. Louis Pasteur's Patents, 327 SCIENCE 86, 86 (1937). But such patents were extremely rare.

27. See, e.g., TOM REgan, THE CASE FOR ANIMAL RIGHTS (1983): PETER Singer, ANIMAL. LibERATION (2d ed. 1990); $c f$. VANDANa SHIVA, BIOPIRACY: THE PLuNDER OF NATURE AND KNOWLEDGE 23 (1997) (arguing that patenting plants and animals is morally wrong because such patents deny organisms their "self-organizing capacity" and "self-reproducing capacity"); PAUL W. TAYLOR, RESPECT FOR NATURE: A THEORY OF ENVIRONMENTAL ETHICS (1986) (espousing the theory of "biocentric egalitarianism," which argues that all living creatures are morally equal). 
to pay a licensing fee for the dog's " use." Further, the patent holder could preclude everyone else from having a Dachshund. Arguably, the patent owner could even prevent anyone from breeding Dachshunds-the most extreme and troubling possibility. It is this broad, exclusive ownership that has troubled many people. ${ }^{28}$

Second, others argued that granting such patents would unjustly enrich those who were simply the first to apply for a patent on a naturally occurring organism. ${ }^{29}$ In this sense, patenting life would become a race to the patent board, allowing the fastest applicant to exclude all others from the use of a particular plant or animal. This objection raises a question of equity: Is it fair that someone have exclusive rights to a natural product when she has not done anything more than fill out a set of forms correctly?

Third, in an argument related to the second, some invoked a Lockean philosophy of labor and just deserts in contending that live-organism patents were inappropriate because they did not require the patent holders to mix their labor with the naturally occurring item. ${ }^{30}$ Patents are rewards for those who have invested their energy in innovation. If an individual patents a product of nature, there is no innovation or work invested in its development. Again, the patent process just becomes a meritless winnertake-all race to the PTO. Thus, according to this critique, patent applicants should have no claim to organisms that rightfully belong to nature. ${ }^{31}$

Simultaneously, genetics and evolution were gaining attention through rather infamous events. In 1925, creationism and evolution clashed in the famous Scopes trial. Although creationism won at trial, the controversy itself revealed the growing acceptance and credibility of evolution in education. $^{32}$ The late 1920 s also saw the ugly growth of the eugenics movement. Politicians and ideologues adopted the scientific language of evolution and genetics to justify social stratification and oppression in

28. It should be noted here that these restrictions would be limited to the term of the patent. which can vary under federal law.

29. See O'Reilly, 56 U.S. (15 How.) at 132-33.

30. Cf. Baruch Brody, Should We Allow the Patenting of Life?, AGRIC. BIOETHICS F., Aug. 1991, at 4 (arguing for patent rights as just deserts). For John Locke's original discussion, sec JOHN LOCKE, SECOND TREATISE OF GOVERNMENT 8-30 (C.B. Macpherson ed., Hackett Publ'g. Co. 1980) (1690).

31. Arguably, the basic patent requirements themselves are founded on these same principles. In most cases, it can be argued that the novelty requirement implicitly uses naturally occurring items as a baseline for comparison. Presumably, anything that is novel must, at the very least, not be found in nature. The utility requirement also relates to the fundamental principles by forcing applicants to explain the use of the item under review. In other words, something that simply exists naturally is not necessarily worthy of patent protection. For a discussion of the utility requirement in biotechnology law, see Christopher A. Michaels, Biotechnology and the Requirement for Utility in Patent Law, 76 J. PAT. \& TRADEMARK OFF. SOC'Y 247 (1994).

32. See MiChaEl BARONE, OUR COUNTRY: THE SHAPING OF AMERICA FROM ROOSEVElT TO REAGAN 25 (1990). 
society. ${ }^{33}$ Eugenics would later provide one of the key principles that Adolf Hitler used to justify the Holocaust. ${ }^{34}$

It is against this backdrop that we may better understand the exclusion of evolutionary biology in patent doctrine. First, evolution ran counter to two millennia of biblical tradition and doctrine. Man was a creation in God's image-not a natural product that evolved from apes. Second, the political use of the theory had less-than-favorable results, leading many to question the appropriateness of its application beyond the context of pure scientific theory. Finally, the theory itself was still in its developmental stages and did not have the widespread acceptance within the scientific community that it enjoys today. Thus, it actually seems quite logical that politicians, courts, and lawyers avoided the application of evolutionary theory either as a means of denying patent protection to living organisms or as the basis for a challenge to the existing doctrine. Put differently, evolutionary biology may have been considered "taboo" during the early period of the live-organism controversy; consequently, all parties to the animal- and plant-patent debate steered clear of the negative stigma attached to the concept. ${ }^{35}$

\section{B. Plant-Patent Legislation}

In 1930, Congress, recognizing the impact that new technologies were having on the breeding and cultivation of plants, passed the first Plant Patent Act. ${ }^{36}$ The Act lifted the absolute bar against issuing patents on plants, but only for asexually reproducing plants and only in a narrowly defined set of circumstances. In relevant part, the statute reads,

Whoever invents or discovers and asexually reproduces any distinct and new variety of plant, including cultivated spores, mutants, hybrids, and newly found seedlings, other than a tuber-propagated plant or a plant found in an uncultivated state, may obtain a patent therefor, subject to the conditions and requirements of this title. ${ }^{37}$

33. See Michael OMI \& Howard Winant, RaCial Formation IN the Untted States: FROM THE 1960S TO THE 1990s, at 14-15 (2d ed. 1994).

34. See ADOLF HITLER, MEIN KAMPF 284-96 (Ralph Manheim trans., Houghton Mifnin 1971) (1925) (arguing that the superiority of the Aryan race would lead to the cradication of Jews, Gypsies, and the handicapped in the name of species purity).

35. Of course, there are a variety of other plausible reasons for the initial exclusion of evolutionary biology from the discourse on plant patents. This hypothesis is one way of explaining a common problem facing all policy issues that touch upon Darwinism and the principles of evolution.

36. 35 U.S.C. $\S \S 161-164$ (1994).

37. Id. § 161; see also U.S. Patent \& Trademark Office Manual of Patent EXAMINATION PROCEDURE § 1601 (15th rev. 1993) (providing a more detailed analysis of the statute). The explicit exclusion of "tuber propagated plants" was a political distinction that 
Congress hoped that the Act would stimulate economic activity in the plantbreeding industry, ${ }^{38}$ but the constraints on the subject matter stifled the impact of the 1930 Act.

The Plant Patent Act has several structural problems that have hindered the effective and accurate review of plant-patent applications. By limiting patentability to asexually reproducing plants, Congress placed the focus of the review process on the method by which the plants were bred and cultivated. Asexual reproduction takes the form of clipping, grafting, or budding. ${ }^{39}$ In some sense, plant patents became more akin to process patents than to utility patents, which they were theoretically supposed to parallel..$^{40}$ Thus, it is not the organism itself that receives review but the method of its creation. ${ }^{41}$ This result has had the effect of further reducing the set of plants that are eligible for patent protection.

Despite its limited effect, the 1930 Act remains a significant event in the historical development of plant and animal patents because it contains the first set of legal rules that attempt to define a patentable, living organism. In the Act's legislative history, distinctiveness is addressed as follows: "The characteristics that may distinguish a new variety would include, among others, those of habit; immunity from disease; or soil conditions; color of flower, leaf, fruit or stems; flavor; productivity, including everbearing quantities; perfume; form; and ease of asexual reproduction." 42 The use of these criteria is a departure from the

pertained only to Irish potatoes and Jerusalem artichokes. See Nicholas J. Seay, Protecting the Seeds of Innovation: Patenting Plants, 16 AM. INTELL. PROP. L. ASs'N Q.J. 418, 420-21 (1989).

38. See In re Bergy, 596 F.2d 952, 982 (C.C.P.A. 1979).

39. The Act also has had the effect of excluding seeds from patent protection because they are the products of sexual reproduction.

40. See 35 U.S.C. \& 161. Many of the animal and plant patents at issue in this Note also appear to be process patents rather than standard utility patents. Defined simply, process patents protect a novel procedure developed for the creation or production of a given item. See DONALD S. Chisum et Al., PRinCiples OF Patent LaW 753 (1998). Utility patents protect a novel product that is created for a particular use. See GOLDSTEIN, supra note 17, at 458-59. The difference between the types of patents is relevant to the future use and development of similar organisms. A process patent protects only a procedure; consequently, others can make the same product so long as they employ a different process. A utility patent, however, would temporarily bar future developers from creating the same product, provided it is used for the same purpose. For a detailed discussion of the distinctions between these two types of patents as used for biotechnological products, see Seide \& MacLeod, supra note 11, at 381 .

Given the nature of the judicial and administrative regime, animal and plant patents should be a form of utility patent because the genetic engineering techniques themselves can be used to produce multiple products that are not eligible for patent protection themselves. Yet given the ethical and moral questions surrounding the subject matter, scientists may actually find it easier to craft an application that describes the process, shifting attention away from the animal or plant and toward a more objective procedure. See generally Breffni Baggot, Legislating a Transgenics Revolution, INTELL. PROP. MAG., May 1998, at 371 (noting this possibility for animal-patent applicants).

41. Cf. Brian C. Cannon, Toward a Clear Standard of Obviousness for Biotechnology Patents, 79 CORNELL L. REv. 735 (1994) (proposing a review of biotechnological patents that focuses on the nonobviousness of the process described in the patent application).

42. S. REP. NO. 71-315, at 1 (1930). 
requirements for standard utility patents, ${ }^{43}$ but has formed the foundation for the development of standards in the modern doctrine.

In 1952, Congress renewed and revised the Plant Patent Act along with the general patent law. The Act has subsequently been amended on several occasions and has been shaped through litigation, -4 but the basic requirements and rules remain the same. The Plant Patent Act remains the standard by which the courts, the PTO, and legislators measure their decisions related to the extension of patent protection to new species of plants and animals. The Act, however, was found to be insufficient in at least one respect.

In 1970, Congress passed the Plant Variety Protection Act ${ }^{\text {is }}$ (PVPA) as a means of affording some exclusive rights to breeders of sexually reproducing plants, thereby extending some limited protection to the large number of plants excluded by the Plant Patent Act. ${ }^{46}$ The PVPA is administered by the U.S. Department of Agriculture (USDA), not the PTO. The USDA is authorized to issue a "Certificate of Plant Variety Protection" that grants limited exclusive rights over certain types of plants. ${ }^{47}$

The qualifications for receiving a certificate roughly parallel the requirements for an asexual plant patent. ${ }^{48}$ But the protections under the PVPA are substantially fewer than those provided by a patent. Certificate holders are required to license their technology upon the reasonable request of an interested party and have no blanket authority to exclude at will. ${ }^{49} \mathrm{~A}$

43. See Seay, supra note 37 , at 421.

44. See, e.g., In re LeGrice, 301 F.2d 929 (C.C.P.A. 1962); Ex parte Hibberd, 227 U.S.P.Q. (BNA) 443 (Bd. Patent App. \& Int. 1985).

45. 7 U.S.C. $\S \S 2321-2582$ (1994). The initial discussion that led to the development of the PVPA was fostered by the establishment of the International Union for the Protection of New Varieties of Plants, an organization that oversaw the issuance of certificates to protect seedproducing (that is, sexually reproductive) plants. Thus, it was changes in intemational law that pressured the United States to alter its existing doctrine. This point underscores a more fundamental problem in U.S. patent law: The rules and regulations in other countries can evolve at a much faster pace than those of the United States. International legal concerns have been an integral part of the debate over plant and animal patents; however, it is the United States that is pressing forward at a rate that alarms the international intellectual-property community. See James Buchanan, Between Advocacy and Responsibility: The Challenge of Biotechnology for International Law, 1 BUFF. J. INT'L L. 221 (1994); Seay, supra note 37, at 423; Darrell G. Dotson, Comment, The European Controversy over Genetic-Engineering Patents, 19 Hous. J. INT'L L. 919 (1997).

46. As one commentator notes,

The technology of plant breeding had developed sufficiently between 1930 and 1970 that there was a generalized perception that new sexually reproduced varieties could be replicated true-to-type in a way that was not thought possible in 1930. Sexually reproduced varieties are non-hybrid varieties or cultivars that, for practical purposes. breed true-to-form when self-pollinated.

Seay, supra note 37 , at 423.

47. See 7 U.S.C. $\$ 2483$.

48. See Seay, supra note 37 , at 424.

49. See 7 U.S.C. \$ 2404. 
mandatory exception to protection is granted for research use of any certified plant. ${ }^{50}$ Also, there are specific statutory exemptions for the sale, purchase, and distribution of seeds obtained from the certified plants. ${ }^{51}$ Clearly, the certificates are designed to permit legitimate use in a scheme similar to the "reasonable royalty" structure employed in other patent cases and commonly used under copyright law. ${ }^{52}$

Although these various congressional acts served as catalysts in the extension of patent protection to plants and animals, they did little to establish a well-defined set of rules and guidelines for subject-matter review. By focusing on the wrong aspects of the living products-the process by which they are created-or by establishing criteria that would prove confusing when applied-a compulsory licensing scheme that cuts against the ostensibly absolute sanctity of naturally occurring organismsCongress actually laid the faulty foundation upon which the PTO and the courts would later construct today's problematic doctrine.

Further complicating this situation was the striking absence of scientific analysis in the review process. As mentioned above, the social and political climate in which Congress considered the 1930 Act did not favor evolutionary biology. Thus, its omission in this period is not surprising. Indeed, it was only after technological advancements in genetic research during the 1960s that evolutionary biology gained complete acceptance in the scientific academy. Yet the plant acts have remained devoid of any mention of the theory, despite the changing attitudes toward the scholarship and the opportunity for legislative revision. Evolutionary biology is the framework within which we appreciate the importance of genetic technology and understand the power of biotechnological research. Given the importance of the acts, the theory's absence has, at least in part, contributed to the confused doctrine by robbing policymakers and scholars of a valuable perspective in the overall progress of the law and science.

\section{Diamond v. Chakrabarty to the Present}

Over the last two decades, litigation, rather than legislation, has molded the law regarding plant and animal patents. A series of decisions by the U.S. Supreme Court and the Federal Circuit served as the driving force that led to the end of the absolute prohibition on animal and plant patents. In

50. See id. § 2544 .

51. See id. $\$ 2543$.

52. For an example of a reasonable-royalty scheme in patent law, see Broadview Chem. Corp. v. Loctite Corp., 311 F. Supp. 447 (D. Conn. 1970). For an example of the reasonableroyalty scheme in copyright law, see Sid \& Marty Krofft Television Prods. v. McDonald's Corp.. 562 F.2d 1157 (9th Cir. 1977). 
Diamond v. Chakrabarty ${ }^{53}$ the Court ordered the issuance of a patent for a genetically engineered, oil-digesting bacterium-the first patent granted on a nonbotanic living organism. The developers of the bacterium originally sought a patent under the guise of a plant-patent application, claiming that bacteria were not "animals" per se and that the developer's rights and interests were analogous to those of plant breeders. The PTO denied the application, holding merely that the Plant Patent Act did not consider bacteria appropriate subject matter.

The Court agreed with the PTO's position regarding the exclusion of bacteria from the Plant Patent Act. But the Court also agreed with the applicants' argument that their bacterium was patentable subject matter, and therefore ruled that the researchers had developed a process and a product that were substantially different from the organism's progenitors found in nature. The researchers' product was innovative and had value; therefore, it qualified for protection. The Court, quoting the legislative history of the 1952 Patent Act renewal, wrote the now famous passage:

The relevant legislative history also supports a broad construction. The Patent Act of 1793, originally authored by Thomas Jefferson, defined statutory subject matter as "any new and useful art, machine, manufacture, or composition of matter, or any new or useful improvement [thereof]." The Act embodied Jefferson's philosophy that "ingenuity should receive a liberal encouragement." Subsequent patent statutes in 1836, 1870, and 1874 employed this same broad language. In 1952, when the patent laws were recodified, Congress replaced the word "art" with "process," but otherwise left Jefferson's language intact. The Committee Reports accompanying the 1952 Act inform us that Congress intended statutory subject matter to "include anything under the sun that is made by man." 54

On the basis of this language, the Court not only allowed the bacteria patent, but appeared to expand the universe of patent protection to any product of man, even to animals that were man-made. Although bacteria are quite different from multicellular animals, the Court's decision opened the door to claims on other living organisms not explicitly included in the Plant Patent Act. This case, together with the plant acts, forms the foundation for the modern proposition that bioengineered organisms are no longer presumptively barred from patent protection.

Subsequent to this ruling, numerous parties sought to claim exclusive rights to other animals and previously unpatentable plants (or plant parts) under the expanded scope of patent protection. The PTO and the Federal

53. 447 U.S. 303 (1980).

54. Id. at 308-09 (citations omitted) (emphasis added). 
Circuit, working amid the uneasiness and uncertainty of the Court's ruling, generally denied the patent applications, often resting their opinions on details quite remote from the issue of patenting life. A series of cases developed to test the boundaries of the law, ${ }^{55}$ and numerous special interest groups, seeking to reverse the permissive trend toward patenting life, entered the fray to challenge the policy's legal foundations.

In 1991, the Federal Circuit addressed the patentability question in dicta in Animal Legal Defense Fund v. Quigg. ${ }^{56}$ In Quigg, the court held that an organism, "given a new form, quality, properties or combination not present in the original article existing in nature in accordance with existing law," ${ }^{57}$ could be patented. The court wrote further,

Accordingly, the Patent and Trademark Office is now examining claims directed to multicellular living organisms, including animals. To the extent that the claimed subject matter is directed to a non-human "nonnaturally occurring manufacture or composition of matter-a product of human ingenuity," such claims will not be rejected under 35 U.S.C. 101 as being directed to nonstatutory subject matter..$^{58}$

This holding has become the definitive statement on the patentability of living organisms. Although the Federal Circuit never addressed the moral and philosophical claims proffered by the plaintiffs in Quigg, the ruling has served as the basis for granting animal patents to date..$^{59}$

But the Chakrabarty and Quigg courts made no attempt to elucidate scientific standards that could be employed in reviewing plant and animal patents. Perhaps the Justices and judges concluded that there was no need to impose scientific standards or felt ill-equipped to make such a judgment. It seems even more remarkable that in the opinions of the cases litigated in the years between Chakrabarty and Quigg, jurists have made no statements about, nor requests for, scientific data related to evolution theory-not even in a footnote. ${ }^{60}$

55. See In re Vaeck, 947 F.2d 488 (Fed. Cir. 1991) (reviewing the patentability of cyanobacteria); Amgen, Inc. v. Chugai Pharm. Co., 927 F.2d 1200 (Fed. Cir. 1991) (reviewing the patentability of human genetic material); In re O'Farrell, 853 F.2d 894 (Fed. Cir. 1988) (reviewing the patentability of a protein-enhanced bacterium); In re Allen, No. 87-1393, 1988 WL 23321 (Fed. Cir. Mar. 14, 1988) (reviewing the patentability of oysters); Ex parte Hibberd, 227 U.S.P.Q. (BNA) 443 (Bd. of Patent App. \& Int. 1985) (reviewing the patentability of seeds and plant tissue).

56. 932 F.2d 920 (Fed. Cir. 1991).

57. Id. at 923 .

58. Id. (citations omitted).

59. Plant patents and certificates remain regulated by the Plant Patent Act and the PVPA.

60. Of course, it is impossible to know whether evolutionary biology was ever entertained as a possible solution to the lack of standards. But no court appears to have called for its adoption or even relied on its basic principles for guidance. Perhaps it has been considered or presented during 
In the wake of Quigg, the standards of patent review for living organisms remain unclear. A backlog of applications and appeals has accumulated at the PTO, and little has been done to solve the problem. The PTO and the courts continue to work on a slow, inconsistent, case-by-case basis. Given the rapid nature of the technology and the value to its potential owners and the scientific community in general, these problems cannot persist. Thus, a new set of standards must be developed to bring clarity to the situation.

\section{APPLICATION OF EVOLUTIONARY BIOLOGY}

There are two facets of plant- and animal-patent technology that can be probed and assessed through a test based on evolutionary biology: organism development and species survival. As briefly mentioned in Part I, an examination of these two areas will provide patent reviewers with objective, quantifiable values that reveal the hand of man and allow for comparisons between various applications. This Note proposes that the integration of evolutionary biology take the form of a two-part inquiry. In the first part of the test, applicants must show that the organism under review would have little chance of developing naturally. In the test's second part, applicants must also provide evidence that natural selection would actually work against the organism but for the intervention of human interest and technology. Only those organisms that satisfy both prongs of the test would receive patent protection.

This proposal is a radical shift from the case-by-case analysis currently employed by the PTO. The PTO appears to have avoided the establishment of formal rules and standards by which it assesses the patentability of living subject matter. ${ }^{61}$ As this Part will show, the absence of even the most basic regulatory analytic structure has resulted in the issuance of a number of questionable patents and a lack of predictable results in the application process. For example, although patents on transgenic animals and plants are commonly considered a form of utility patent, there are a number of patents that actually describe processes of producing the animals and not the

oral arguments, but the absence of any reference at least accentuates its widespread omission in the legal system.

61. At present, the PTO does not have a published circular discussing the standards of patent review for nonhuman, multicellular organisms. In an informal discussion with several patent officers regarding the standards that they employ when reviewing such patent applications, there was no mention of a formal rule and only reference by analogy to animals that had already been patented. Although informal rulemaking is inherent in the administrative legal regime, the lack of formal rules and reliance on amorphous standards appear highly problematic given the controversial nature of such patents. 
animals themselves. ${ }^{62}$ Some of this confusion can be traced to a lack of clarity regarding the form that biotechnological patents should take. ${ }^{63}$

The two-part test proposed here responds to the current confusion by adopting scientific standards to reveal the hand of man in "creating" these organisms. It further attempts to confine the grant of patent protection to those organisms that are so disfavored by natural selection that they must be the products of human technology and not nature: They are effectively man-made even if they are living organisms. The former goal is one of simple efficiency and clarity. The latter goal is an attempt to create a selfimposed limit on the scope of animal- and plant-patent protectionsomething absent in the current regime. ${ }^{64}$ Although neither goal may be fully reached, the following Sections seek to show, at the very least, how the infusion of a few basic scientific principles can relieve some of the uncertainty and anxiety in this controversial and politicized area of the law.

\section{A. Organism Development}

Evolutionary development is the measurable expression of genetic progress. Phenotypic changes in the morphology and behavior of an

62. These patents describe processes that could be used to produce any number of different types of transgenic animals. See, e.g., U.S. Patent No. 5,859,310 (Jan. 12, 1999) (patenting a process to create transgenic animals used in tetracycline research); U.S. Patent No. 5,852,224 (Dec. 22, 1998) (patenting a process to prepare transgenic animals to produce human enzymes in their milk); U.S. Patent No. $5,843,652$ (Dec. 1, 1998) (patenting a process to produce transgenic animals that carry a specific strand of human DNA important to diabetes research); U.S. Patent No. 5,824,287 (Oct. 20, 1998) (patenting a process to produce transgenic animals that carry a specific strand of human DNA important to cancer research); U.S. Patent No. 5,792,901 (Aug. 11. 1998) (patenting a process for using transgenic animals to detect prions in genetic tests); U.S. Patent No. 5,625,126 (Apr. 29, 1997) (patenting a process that produces transgenic animals that produce certain human antibodies). Thus, anyone using the methods described in these patents could produce transgenic mice, dogs, cows, or sheep that express the same characteristic. Arguably, it is the process and not the animal that deserves patent protection.

In addition, some patented processes produce transgenic animals only as a by-product. See, e.g., U.S. Patent No. 5,888,981 (Mar. 30, 1999) (patenting a process that produces transgenic animals as a result of a test for the impact of certain chemicals on human proteins); U.S. Patent No. 5,888,774 (Mar. 30, 1999) (patenting a process that produces transgenic animals as a result of a test for the genetic expression of certain types of human proteins); U.S. Patent No. 5,876,949 (Mar. 2, 1999) (patenting a process that produces transgenic animals as a by-product of producing certain human antibodies used in medical research); U.S. Patent No. 5,633,076 (May 27. 1997) (patenting a process that produces transgenic bovines that produce protein-enhanced milk). Again, these patents emphasize process over product.

63. See generally Baggot, supra note 40 , at 371 (noting that a patent on an animal or plant may describe the invention in several different ways).

64. Admittedly, this small step is taken in response to the ethical and moral criticism leveled against plant and animal patents that, according to the discussion in Part $\mathrm{I}$, was to be avoided in this Note. This goal is mentioned here, however, to stress the superiority of this Note's proposal to the current system. Simply having defined limits on the scope of a potentially powerful set of rights is, objectively speaking, favorable to a system in which the boundaries are arbitrary. Thus, the statement of this goal is not an attempt to legitimate the proposal in the eyes of those who challenge the propriety of plant and animal patents. Rather, it is a statement in favor of formalism in the patent-review process for live organisms. 
organism affect the rate of its natural selection; ${ }^{65}$ consequently, genetic and physical development is the dependent variable in the evolution equation. Biotechnology seeks to control that variable by allowing researchers to manipulate the evolutionary course of a given species. ${ }^{66}$ Thus, an appraisal of the level of human involvement in the development process is certainly relevant to an assessment of the novelty, nonobviousness, and utility of a given bioengineered animal or plant that are required under general patent law. This evaluation constitutes the first part of this Note's proposed test.

Mutation is the most common natural reason for genetic change. ${ }^{67}$ Genetic variation within a species may also be the product of other factors, such as genetic drift, ${ }^{68}$ fission, ${ }^{69}$ or adaptive polymorphism. ${ }^{70}$ The probability of such naturally occurring events then becomes the baseline for comparison in the proposed test. Although it may seem counterintuitive, even genetically altered organisms have a calculable probability of occurring naturally. ${ }^{11}$ The probability of such animals' developing may be so low that it is, in reality, a statistical impossibility. In such instances, the influence of biotechnology on the actual existence of the organism is evidently too high to deny patent protection outright. Thus, under the proposed test, probability of natural occurrence would be inversely related to patentability.

The application of evolutionary biology in the patent-review process offers the possibility of calculating the probability of an organism's natural occurrence. By employing quantitative analyses from the subfields of genetics and population ecology (discussed below), patent applicants could undertake such calculations by using dozens of formulas or statistical models that scientists have developed to evaluate the evolutionary process. $^{72}$ Their results could then be presented to the PTO for review. There is no one equation or model that tells us the probability of an organism's natural occurrence. Different tests or models apply to different species in different environments. In fact, the proposed test would likely

65. See FuTUYMA, supra note 20 , at 146.

66. Or at least to open an alternative path of development unavailable in nature.

67. For a general discussion of the important role mutation plays in evolution, see THEODOSIUS DOBZHANSKY, GENETICS AND THE ORIGIN OF SPECIES $50-75$ (3d ed. 1951).

68. See FUTUYMA, supra note 20, at 142-47.

69. See Ronald A. Fisher, The Genetical. Theory of Natural SElection 139-43 (2d rev. ed. 1958).

70. See DOBZHANSKY, supra note 67 , at 108-34.

71. Technically, there is always a possibility of an organism's occurrence given the random and sometimes dramatic change caused by mutation.

72. For detailed discussions of such equations and models, see generally AYALA, supra note 20; DOBZHANSKY, supra note 67; FISHER, supra note 69; and FUTUYMA, supra note 20. For example, the Hardy-Weinberg Law, an elementary theory of genetics, provides a foundation for many of these calculations and would be a starting point for the statistical analysis of the patent process. See AYALA, supra note 20, at $60-71$. It is from such basic principles of scientific theory that a quantitative analysis of natural selection and man-made cvolution can begin. 
require a battery of calculations to support the "man-made" characterization of a given organism. The results of these tests would be measured against standards established by the PTO.

The use of PTO-established standards may raise doubts for some people. If there is so much variation in the statistical modeling of evolution, one might ask, how can any standards be established? This criticism is certainly valid. Standards may have to be adjusted for different environments or situations, but there is no reason the PTO could not establish a set of standards for a variety of situations. In difficult and unexpected cases, the patent reviewers could further adjust the scores to ensure a fair assessment of the application. Although this may seem to resemble the current case-by-case system, the two tests are quite different for several reasons. First, evolutionary biology has identifiable standards that provide some level of notice and expectation for patent applicants. Second, this proposal employs a more formalistic procedure than the ad hoc system that allows process to be considered in lieu of product. Third, the proposed system uses objective, quantifiable methods as its foundationnot subjective, amorphous concepts. Finally, it sets a clear bar that all applicants must initially pass, which may lead to a reduction in the number of patents filed and alleviate the mounting backlog in the system.

Upon surveying the patents already issued for bioengineered organisms ${ }^{73}$ we find that many meet this initial standard. For example, a number of patented animals are the products of gene-splicing, in which human DNA peptide strands are inserted into the genetic sequence of the target organism. ${ }^{74}$ The probability of this occurring naturally is very low. ${ }^{75}$ Genes of one species do not naturally splice into those of another. Most of the already patented transgenic ${ }^{76}$ animals have had a human gene inserted within the DNA sequence. ${ }^{77}$ Under the evolutionary biology model, such

73. This Note can comment on only those patents that have been issued or that have been openly discussed in the media. All patent applications and supporting material, as well as any related PTO dispositions, are kept confidential to avoid any direct or inadvertent disclosure of trade secrets. Thus, no comment on, or example of, patents recently denied by the PTO can be offered.

74. See, e.g., patents cited infra note 97.

75. By definition, a species generally defines a group of common breeding. See FUTUYMA. supra note 20 , at 111 . Thus, crossbreeding between most species, while not impossible, is unlikely. Further, in certain instances, fundamental genetic coding makes the creation of interspecies progeny impossible. See id. For example, one reason a mammal could not interbreed with an insect is that the number of chromosomes do not match. Genetic splicing, however, allows scientists to insert genetic codes from one animal to another, making the naturally impossible a reality.

76. The term "transgenic" itself underscores the rarity of such an organism. Again, basic biology principles dictate that organisms of different genuses cannot breed.

77. For general descriptions of such patents, see Landau, supra note 6; Sellers, supra note 6; Greene, supra note 15; and Sally Lehrman, PTO Issues First r-DNA Animal Patents Since Harvard Mouse, BIOTECHNOLOGY NEWSWATCH, Jan. 4, 1993, at 1. 
animals would be nearly impossible to find in the wild and, therefore, are presumptively patentable.

Rather than engaging in rigorous scientific inquiry, however, the PTO has approved dozens of other applications simply because the procedure by which the organisms were created was novel or nonobvious to the average individual working in the industry. ${ }^{78}$ Akin to the confusion inherent in the process established by the Plant Patent Act, the lack of guidance in the patent-application process for animals has led the PTO and the courts to shift the focus away from substance and toward process. For example, suppose a group of researchers were to alter the genotype of a rat to achieve a specific phenotypic expression. When applying for their rat patent, they describe the process by which it is created as being novel, but are legally seeking protection for the rat itself. If the PTO issues the patent, the researchers now have rights over both process and product, but have still failed to explain how the rat itself is novel or nonobvious. ${ }^{79}$ Under the current system, the rat could be patented with such an incomplete and flawed application. The existence of these types of patents ${ }^{80}$ raises the question of what exactly is being patented, which evokes the additional question of what is patentable.

The evolutionary biology test avoids this trap by shifting attention away from the production process. A showing of human intervention is required to file for a patent in the first part of the test. This basic requirement prevents the direct appropriation of naturally occurring organisms. ${ }^{81}$ Although the methods the applicants use will have some bearing on the quantifiable calculations, the evolutionary biology test does not assume that a biotechnologically altered organism is inherently man-made. It goes a step further to calculate and examine the probability of the organism's natural development as part of the first prong of the proposed test.

The current patent system fails to recognize the possibility that the same "new" organism could develop both in a laboratory and in the wild. Organisms do not need to be the products of complex genetic manipulation to receive protection under the current doctrine. ${ }^{82}$ For example, plant

78. See, e.g., patents cited supra note 62 .

79. This scenario, of course, assumes that the rat meets the utility requirements for patent protection.

80. See, e.g., patents cited supra note 62 .

81. To meet this requirement, an applicant would have to describe the process by which she created the organism and provide evidence that the procedure is reproducible and consistent. This statement may seem at odds with the contention that the evolutionary biology test shifts the focus away from process and toward substance. In contrast to the current system. this prima facie showing is not the only relevant factor. It is merely a way to prevent an applicant from attempting to patent an uncatalogued organism found in the wild. Given Earth's immense biodiversity and continual development, the possibility of such a fraudulent application is a relevant concem.

82. See Greene, supra note 15, at 17; Weiss, supra note 5; $c f$. John Woodley. Act Should Permit Plant and Animal Patents, LAW. WKLY., Sept. 10, 1999, at 21 (noting that Canada does 
breeders often employ the "old-fashioned" process of cross-pollination to create hybrids. ${ }^{83}$ Currently, these plants can and often do receive certificates under the Plant Variety and Protection Act (PVPA). ${ }^{84}$ Again, there is inconsistency in the certificate-application process due to a misplaced focus on the procedures used to create the plant, ${ }^{85}$ but a survey of the issued certificates reveals that crossbreeding is a common procedure used to create new hybrids and variations of sexually reproductive plants. The evolutionary biology test would reveal the PVPA's scope to be overbroad.

Population ecology, a subfield of evolutionary biology, examines the ways in which reproductive processes, such as cross-pollination, operate in nature. Studies have shown that cross-pollination occurs quite frequently in nature and can take place over substantially long distances. ${ }^{86}$ Probabilities of naturally occurring plant hybrids can be high relative to mutations. The already existing analyses of population dynamics and natural reproductive processes can be brought to bear upon the review of plant and animal patents, possibly exposing organisms that are unworthy of patent (or certificate) protection.

For example, the PTO has issued several patents for herbicide-resistant plants. ${ }^{87}$ Such plants are generally the result of some form of bioengineering-DNA splicing or resequencing. But these plants could easily develop in the wild through exposure to the same regimen of chemicals or through natural mutation. ${ }^{88}$ Herbicide resistance, for example, is a common natural occurrence that does not require human intervention to

not permit patents on most non-biotechnologically developed animals that have long been considered patentable material in the United States).

83. See Weiss, supra note 5.

84. See Eric M. Bram, Federal Legal Protection for Plants, INTELL. Prop. TODAY, Dec. 1994 , at 5.

85. The PVPA limits the certificate protection to plants created through sexual processes. In most cases, such processes would involve cross-pollination techniques and selected breeding to produce the desired result. In their basic form, these processes are no different from natural reproduction, and some of these plants may actually occur in nature under the right conditions and should, therefore, be excluded from patent protection.

86. For a general discussion of such natural occurrences, see SHERWIN CARLQUIST, HAWAII, a Natural history: Geology, Climate, native flora and Fauna above the: SHORELINE (1980); and SHERWIN CARLQUIST, ISLAND BIOLOGY (1974).

87. See, e.g., U.S. Patent No. 5,955,361 (Sept. 21, 1999) (patenting a transgenic plant resistant to herbicides, pesticides, pests, and pathogens); U.S. Patent No. 5,853,973 (Dec. 29. 1998) (patenting transgenic plants resistant to certain herbicides and pesticides); U.S. Patent No. 5,736,629 (Apr. 7, 1998) (patenting a transgenic variety of rice resistant to certain herbicides); U.S. Patent No. 5,731,180 (Mar. 24, 1998) (patenting the process and plants resulting from the insertion of a monocot gene sequence that fosters the development of pesticide-resistant strains for cultivation).

88. One could liken this reasoning to that of the patent standard for nonobviousness. If we consider nature as a participant in the industry of plant engineering, then the "invention" of a pesticide-resistant strain may be quite obvious. Through mutation or simple desensitizing, plants often grow resistant to chemicals over generations of breeding. Thus, because the plant is an obvious result of natural development, it should not be considered an innovation and should not receive patent protection. 
reach the same result. Although one could argue that technology allows for the more rapid development of resistant strains or that genetic splicing "creates" a species of flora that would never have developed in the wild, the fact remains that there is a relatively high probability that nature's course would produce an organism that expresses the same characteristics as the bioengineered product. ${ }^{89}$

The PTO has granted other patents on plants that actually occur in nature. These plants are often the products of laboratory-induced mutation ${ }^{90}$ or selective breeding, ${ }^{91}$ but they are, in reality, the natural progeny of natural organisms. ${ }^{92}$ Under the proposed evolutionary biology test, these plants would not receive patent protection, because their probability of occurring in nature is too high for them to be characterized as man-made. The application of evolutionary biology would prevent man from claiming credit for creating something that nature would likely have achieved anyway. ${ }^{93}$

89. Further, it is unclear whether natural evolution would really take any longer than bioengineering. Mutations occur in every generation of plant and, if they monitor the plants correctly, breeders may well find resistant strains within one generation of the first use of any chemical.

90. See, e.g., U.S. Patent No. 5,955,071 (Sept. 21, 1999) (patenting a fungal species for biological control that was developed through a process of chemical exposure): U.S. Patent No. 4,761,373 (Aug. 2, 1988) (patenting a plant resistant to certain herbicides that was developed through a process of excessive exposure to the chemicals).

91. See, e.g., U.S. Patent No. 5,962,772 (Oct. 5, 1999) (patenting a hybrid strain of maize that was crossbred from mutants); U.S. Patent No. 5,959,185 (Sept. 28, 1999) (patenting a strain of soybean that was the product of selective breeding); U.S. Patent No. 5.936.148 (Aug. 10. 1999) (patenting an inbred strain of maize resistant to certain plant disease): U.S. Patent No. 5,198,599 (Mar. 30, 1993) (patenting a strain of lettuce that developed pesticide resistance through selective breeding); U.S. Patent No. 5,013,659 (May 7, 1991) (patenting a pesticide-resistant strain of tobacco produced from crossbreeding mutants).

92. One could argue that even plants bred and selected for their resistance to man-made chemicals are man-made. How could they have developed but for the application of pesticides and herbicides? But this argument is only half correct. The plant's exposure to pesticides and herbicides reveals the mutant strains' resistance, but it is unclear whecher the exposure led to the resistance. See FUTUYMA, supra note 20 , at 76 . Mutations occur constantly in nature. In contrast to such genetic techniques as splicing or recombination, it is difficult to tell whether the mutation was natural or a reaction to a particular chemical. This uncertainty does not mean that all plants resistant to pesticides should be presumptively barred from patent protection, only that the issuance of such patents should be highly suspect, given the common occurrence of resistant mutant strains in the wild.

93. One could argue that this characterization of such patents conflates genotype and phenotype. This may very well be true. Two plants may exhibit the same trait (phenotype)pesticide resistance, for example-but have different DNA coding (genotype). But the evolutionary biology proposal is about relative probabilities of natural occurrence. Thus, genetic manipulation may produce the same expressed trait, but this does not mean that the trait is most likely to occur exclusively in a laboratory, nor does it even support the claim that such a trait is more likely to be produced through DNA splicing. If a narural process (natural selection) has a relatively high probability of producing the same result, then the evolutionary biology test would deny patent protection. In this sense, the more likely the phenotypes appear through both natural and artificial processes, the lower the chances of the arificial product receiving a patent. 
The evolutionary biology test allows for analysis in other situations. Beyond ecological and genetic factors, behavioral characteristics can be included in the analysis. ${ }^{94}$ The interaction of other environmental factors can be anticipated in the calculations, allowing for a more comprehensive study of the natural development of a particular organism. Thus, the evolutionary biology test is an improvement on the current system not just because of the objective standards of review it offers, but also because it allows for a more complete analysis of the factors that can determine the novelty and utility of an organism influenced by human technology.

\section{B. Species Survival}

Natural selection is at the core of the evolutionary biology test. Darwin's innovation revolutionized the way that population dynamics and species-survival rates were conceptualized. When combined with the scientific art of genetic technology, the theory works to explain much of the development of the natural world through quantifiable values and by employing objective techniques. Whereas the developmental analysis discussed above asks if a bioengineered organism would appear in nature, the survival analysis presented here asks: Even if such an organism had a low probability of occurring in nature, what would happen if it were introduced into the wild?

The application of natural selection theory is simple. Again, if we assume that the organism for which a patent is sought satisfies the first prong of the evolutionary biology test, a selection rate can be calculated for the new organism. ${ }^{95}$ The analysis takes two forms. First, the organism's natural-selection rate can be determined and compared to other plants and animals-an interspecies comparison. This figure would represent the potential for survival and propagation of the desired trait in the wild relative to other bioengineered organisms. Such a calculation should include variables such as the favorable characteristics of the trait in particular environments, interaction of the questioned trait with other possessed traits, and the genetic probability of the trait's expression. As in the first prong of this test, the PTO or the courts could set general threshold values for plants

94. Animal behavior can play a significant role in the survival rate of a mutant organism. For many species, behavior is a vital element in the mating process. See FUTUYMA, supra note 20, at 231. Those organisms that fail to exhibit the appropriate behavior, whether ritualistic or morphological, may be selected against by potential mates. Thus, a mutant may fail to persist beyond one generation in nature due to its failure to satisfy the behavioral requirements of its progenitor species. See id. at 76 (discussing deleterious mutations).

95. For examples of selection-rate calculations, see AYALA, supra note 20, at 87-116; and FISHER, supra note 69 , at 22-51. As with the formulas and models for calculating natural occurrence cited above, there is no single equation that would work for all species in any environment. Thus, the PTO must again make some effort to tailor the standards and methodology of review to the subject matter for which the patent is sought. 
and animals that would serve as the bar for patent viability. Thus, the organism's natural-selection rate would be compared relative to a predetermined general standard. This approach, however, would be insufficient because it fails to recognize that different types of plants and animals lend themselves better to genetic manipulation or possess complementary traits that may increase the selection index. ${ }^{\%}$

Given the limited nature of the general standard comparison, it is more accurate to conduct the inquiry on an individualized basis. A self-contained, intraspecies comparison would avoid the variances between organisms by requesting the calculation of what may be termed the natural- and the human-selection rates. The natural-selection rate would be the survival probability rate in the wild. The human-selection rate would quantify a plant's or animal's survival rate under its current condition. In most cases, the environment of a bioengineered animal would be a laboratory. The human-selection rate would emphasize the human preferences. If the human-selection rate is higher than the natural-selection rate, a patent could be justified on the grounds that the organism has benefited from some advantage afforded to it on the basis of its utility to humans. Put differently, the organism would die in the wild but continues to exist through human intervention.

For example, the PTO has granted patents on several transgenic animals that are either susceptible to certain diseases at a higher-than-average rate or born with genetic defects that mirror adverse human health conditions. ${ }^{97}$

96. For example, flowering plants generally have two important features that determine their natural-selection rates: scent and coloring. One or both of these traits determinc the plants' success in attracting the appropriate type of insect for pollination. Flowers that bloom at night are normally white and require strong odors to attract nocturnal pollinators, but flowers that bloom during the day are more likely to use color and floral patterns to entice insects. If someone were to bioengineer a night-blooming flower with color, the new trait would likely have little effect on its selection rate because many of the insects that pollinate at night ane colorblind. Insects sensitive to color may be attracted to the flower during the day, but the nower blossoms would be closed. rendering the added attention useless. Thus, the selection rate of the night-blooming plant would be unchanged. But if a day-blooming flower were to add scent and alter its color. there may actually be a substantial increase in its selection rate as a result of the added attention it would receive during its primary reproductive period. For a more detailed discussion of the interaction of insect behavior and plant morphology, see generally A.D. IMIMS, INSECT NATURAL HISTORY (Bloomsbury Books 1990) (1947). Assuming that the PTO did not distinguish between night- and day-blooming plants, the day-blooming plants would experience a higher change in their selection rate than would the night-blooming plants, even though both had gone through substantial changes in their genotypic and phenotypic makcup.

97. See, e.g., U.S. Patent No. 5,859,308 (Jan. 12, 1999) (patenting a transgenic animal that overproduces certain chemicals that cause the animal to be more susceptible to the ill cfrects of stress); U.S. Patent No. 5,789,655 (Aug. 4, 1998) (patenting a transgenic mouse that lacks certain protein genes, resulting in immunodeficiency); U.S. Patent No. 5.789.654 (Aug. 4, 1998) (patenting transgenic animals that are genetically predisposed to obesity): U.S. Patent No. $5,777,194$ (July 7,1998 ) (patenting a mouse genetically expressing symptoms of Alzheimer's disease); U.S. Patent No. 5,777,193 (July 7, 1998) (patenting a transgenic mouse containing cells that have a higher susceptibility to carcinogens); U.S. Patent No. 5.709.844 (Jan. 20. 1998) (patenting a transgenic animal that readily contracts cancer): U.S. Patent No. 5,698,766 (Dec. 16, 
These animals are often used in medical research to examine certain aspects of a disease or the animal's reaction to drugs under development for a new treatment. Natural selection would theoretically work against such creatures. A genetically altered mouse that manifested symptoms similar to degenerative Alzheimer' ${ }^{98}$ or a rat that suffered from a predetermined immunodeficiency ${ }^{99}$ would not fare well in the wild. The expression of these genetic predispositions would not persist, as a result of naturally selective breeding. ${ }^{100}$

Under the evolutionary biology test, these organisms should receive patent protection because they exist contrary to the tendency of natural selection. The force resisting nature is humankind; therefore, the organism could be considered nonnatural and the product of human technology. To use the appropriate terminology, the natural-selection rate is lower than the human-selection rate. In nature, these organisms would have a near-zeropercent survival rate, which would lead to a near-zero-percent expression of the relevant trait in nature. Even with human intervention, these animals have a near-zero-percent survival rate, but their very existence denotes an expression rate higher than what would be expected in nature. ${ }^{101}$

Other transgenic animals are developed for similar purposes, but these would not meet the requirements of the survival inquiry. For example, some organisms are bioengineered to include a genetic marker that expresses a specific trait under defined conditions. ${ }^{102}$ These markers are used to detect

1997) (patenting transgenic animals that are prone to manifesting eating disorders leading to epileptic seizures); U.S. Patent No. 5,675,060 (Oct. 7, 1997) (patenting a transgenic mouse that is genetically predisposed to arthritis).

98. See, e.g., U.S. Patent No. 5,877,399 (Mar. 2, 1999); U.S. Patent No. 5,850,003 (Dec. 15. 1998); U.S. Patent No. 5,811,633 (Sept. 22, 1998); U.S. Patent No. 5,612,486 (Mar. 18, 1997): U.S. Patent No. 5,387,742 (Feb. 7, 1995).

99. See, e.g., U.S. Patent No. 5,859,312 (Jan. 12, 1999); U.S. Patent No. 5.530,179 (June 25. 1996); U.S. Patent No. 5,489,742 (Feb. 6, 1996); U.S. Patent No. 5,434,340 (July 18, 1995); U.S. Patent No. 5,175,384 (Dec. 29, 1992).

100. Natural selection could take several different forms in this context. First, the organism could simply die without ever breeding, thereby precluding any chance of the passing of its genetic trait to another generation. See AYALA, supra note 20, at 98-99. Second, no other member of its species might be willing to breed with the organism, because of its poor health or some potential change in its behavior. See FUTUYMA, supra note 20, at 268-71. Finally, if the trait were recessive, population genetics might simply cause the trait to disappear from the gene pool because of a lack of interbreeding between creatures carrying the recessive trait. See AYALA, supra note 20 , at $71-78$. Under any one of these scenarios, the trait would be disfavored by natural selection and, therefore, would fail to persist in nature.

101. To cast this argument in a different light, one could say that these animals would exist only in a laboratory. Without human intervention, they would die and so too would the characteristic for which humans valued their existence. This recasting of the argument can provide some response to the prevalent fear of many biotechnology opponents that patented animals would be produced in large quantities and escape into the wild where they would adversely affect delicate ecosystems. Cf. Warren D. Woessner, Patenting Life: Transgenic Animals, INTELL. PROP. TODAY, Dec. 1994, at 8 (noting a growing concern over the release of bioengineered animals into the wild).

102. See, e.g., U.S. Patent No. 5,625,123 (Apr. 29, 1997) (patenting transgenic animals that are used to screen for substances that enhance certain types of transcriptional activity); U.S. Patent 
the presence of certain chemical compounds and, in some cases, evaluate their effects on the organism. Although these organisms may not be naturally occurring, their survival rates are often unaffected by their exposure to human technology. They are not created with fatal health problems, nor do these tests ultimately lead to their death. These organisms merely have a quality that is useful to humans but creates little difference between their human- and natural-selection rates. Such animals do not deserve patent protection under the evolutionary biology test. ${ }^{103}$

Such self-contained comparisons create a tension within the patent regulatory process at several levels. First, one could argue that certain nonengineered plants and animals may also express a similar gap between natural- and human-selection rates. Arguably, any cultivated plant or domesticated animal enjoys inflated population levels and selection rates as a result of its value to humanity. ${ }^{104}$ Endangered species are even better examples of such naturally occurring organisms that are sustained by humans. For instance, the California condor would be extinct but for the intervention of humanity. ${ }^{105}$ Under the survival analysis, the condor and other protected species could meet the requirements for the second prong of the evolutionary biology test. But these organisms would not meet the developmental requirements of the test's first prong. The condor is not a product of bioengineering, nor is there a gene-altering process that scientists employ to increase the propagation of the species. Thus, because such creatures do not satisfy the standards of analysis under both prongs of

No. 5,589,155 (Dec. 31, 1996) (patenting a transgenic animal that detects mutagenic compounds); U.S. Patent No. 5,347,075 (Sept. 13, 1994) (patenting transgenic animals that react to certain mutagenic chemicals).

103. One could liken such animals to research instruments, which often receive patent protection. But such an argument would fail to satisfy the requirement that the organisms are, in some sense, "man-made." These creatures are not the equivalent of a gas spectrometer or a centrifuge. They are merely the medium through which a test is performed. One need not patent the entire organism, because it is the DNA strand that is the important element in these organisms (given that the gene is often not host-specific). Thus, they are more akin to the paper on which a reactive chemical is placed (for example, a litmus-paper or a blood-blot test) than to the chemical itself.

104. Cats or some species of dogs would probably not experience such high population levels if they faced the same forces of natural selection as their wild cousins, such as bobcats or coyoles. One could argue that domesticated animals have been "engincered" because they have been trained to serve human masters. But such conditioning neither alters an animal's genetic code nor creates a new organism. For example, the basic genetic sequences of a wild and domesticated horse are identical. Thus, such domesticated animals would be barred from patent protection because they would fail the first prong of the evolutionary biology test.

105. For a discussion of the project to restore the California condor population, see DAVID DARLINGTON, IN CONDOR COUNTRY: A PORTRATT OF A LANDSCAPE, ITS DENIZENS, AND ITS DEFENDERS (1987). For a broader discussion of human intervention and influence regarding endangered species, see ROGER L. DISILVESTRO. THE ENDANGERED KINGDOM: THE STRUGGLE TO SAVE AMERICA'S WILDLIFE (1991). Ironically, the endangered species, like the condor, would probably be thriving were it not for human development polluting their environments. 
the evolutionary biology test, the organisms fail to meet the standards for patentable subject matter.

Second, patent law is fundamentally based on the economic tenet that the potential value of exclusive rights encourages public disclosure of research and development, fostering a more efficient market. ${ }^{106}$ Humanselection rates are inherently influenced by these economic considerations. Some may view the use of a human-selection rate as immoral because it allows economic value to drive environmental management through the patent process. Others may argue that a human-selection standard cannot be compared to the natural-selection rate because economics does not have a bearing on survival rates. But these criticisms would miss the mark. If economic considerations inflate the value of an organism otherwise illsuited for survival, then that result supports the notion that the plant or animal is more like a product of human technology than of natural evolution. At a more theoretical level, economic considerations are themselves constructs of humankind. Thus, the more influence that economics has in the choice of "developing" a particular plant or animal, the more impact humans will have in the propagation of a given organism. Economic influence is, therefore, merely one valuable factor in the analysis of an organism's patentability.

Third, technology may cause the natural-selection rate for a transgenic species to increase to a level that matches or surpasses its human-selection rate. Should this reverse effect occur, one could argue that the selection-rate comparisons would be devoid of probative value. But natural selection theory itself, in conjunction with population ecology, holds the response to this challenge. There exists a theoretical assumption in evolutionary biology that the maintenance of diversity and ecological competition benefits all species. ${ }^{107}$ Put differently, evolution actually does not promote the absolute dominance of one plant or animal species above all others in a given region or class of organisms. When such a dominant species develops, often there is a disruption in the ecological balance of the system that leads to either the collapse of the entire ecosystem or a lack of genetic diversity that weakens the dominant species. ${ }^{108}$ When a species declines, mutations are favored (thereby increasing diversity again), or the species simply falls into extinction. Thus, a man-made plant or animal could also be identified on the basis of selection-rate comparisons within an ecological model that reveals the self-destructive nature of the species.

106. See GOLDSTEIN, supra note 17 , at $15-21$.

107. See DOBZHANSKY, supra note 67, at $69-70$ (discussing the deleterious effects of inbreeding); EHRLICH \& EHRLICH, supra note 20, at 16-32 (discussing the importance of diversity to the prevention of extinction); Paul R. Ehrlich, The Loss of Diversity: Causes and Consequences, in BIODIVERSITY, supra note 20, 24-25 (discussing biodiversity more generally).

108. See works cited supra note 107. 
Finally, one could argue that the comparison of the two rates is inaccurate because the rates may not act in concert. What is a benefit in the wild, from a basic environmental standpoint, may be a detriment when human preference and interference are considered. For example, a coffee plant biologically engineered to produce beans with higher concentrations of caffeine, or a genetically altered tobacco plant with higher levels of nicotine, would most likely be selected for contradictory reasons in the natural and human contexts. Caffeine and nicotine are natural defenses in the wild, but they are chemicals desired for human consumption. This paradox has the effect of increasing both the natural- and human-selection rates. ${ }^{109}$ In these cases, it is perhaps best to take a step back from the rates themselves and examine the underlying causes of the awkward result. If different causes for the two rate increases are identified, this result would only support the patentability of the organism.

Natural selection theory is an elegant and simple concept that welcomes the use of other evolutionary biology principles. In applying this proposed test to patent applications, one could consider the first prong-organism development-as the test for novelty and the second prong-survival examination-as the test for utility, thereby indirectly applying the correct standards required by the U.S. Code. ${ }^{110}$ The use of this test weeds out applications for patents on naturally occurring organisms that are masked by the applicant's description of a man-made process, while rewarding innovation and acknowledging the possibility of nonnaturally occurring organisms.

\section{CONCLUSION}

The evolutionary biology test offers a set of functionally simple rules to evaluate plant and animal patents. It employs quantifiable standards that are consistent with the practices of science and ultimately beneficial to the operation of law. The theory's underlying principles are logical, and, like other types of scientific inquiry, the proposed test encourages consistent and reproducible results. As the PTO and the courts struggle to keep pace with developments in biotechnology and genetic research, processual clarity must become the primary goal of the law of animal and plant

109. This paradox exists for many cultivated plants and domesticated animals. A trait that would normally protect the organism in the wild makes it more valuable to humans, which in tum has a detrimental impact on the survival of the plant or animal. The wild asset becomes a domesticated liability. Ornamental plants are also examples of this paradox. A vibrantly colorful flower would be an advantage in the wild, but if humans often picked this flower. thereby terminating its reproductive life cycle, the beneficial trait would then become a detriment to the plant.

110. See 35 U.S.C. $\S \S 161-164$ (1994). 
patents. Such a goal can be satisfied only by shifting the law toward a more uniform and objective doctrine.

The proposal offered here is an attempt to add formality and legitimacy to the application process for patents on animals and plants. The current system has little of either, but rather stretches outdated legal principles to cover new scientific problems. The simple process that worked for bacteria and tubers is ill-suited for tackling the complexities of transgenic mice or cross-mutated corn. Arguably, if patent law cannot deal with the bioengineered organisms of today, it is most certainly unprepared for the technological advances that lie just over the horizon in the twenty-first century.

As noted in Part I, for example, the PTO currently faces a difficult test case regarding a pending appeal of a denied patent application for chimeras-organisms that are half-human and half-animal. The PTO recently rejected the chimera application on the basis of the government's moral ban on patenting human life, but this justification is suspect at best." As many point out, the PTO regularly grants patents on transgenic animals containing spliced human DNA. These creatures often express human characteristics, such as human hormones or other chemicals that the animal would not produce in nature. ${ }^{12}$ Thus, it appears the PTO's ban is not absolute, and its justification is faulty, leaving the PTO with practically no legal grounds upon which it could deny the chimera patent.

Although the fate of the chimera application appears destined for resolution by the courts, the controversy presents an interesting opportunity to show the superiority of the evolutionary biology test to the current caseby-case system. ${ }^{113}$ First, it would appear that the likelihood of such a

111. This rule is grounded in the Thirteenth Amendment's ban on slavery. See U.S. CONST. amend. XIII. To own any part of a human being would be a form of slavery and therefore unconstitutional.

112. See, e.g., U.S. Patent No. $5,850,000$ (Dec. 15 , 1998) (patenting a transgenic cow that produces certain beneficial human proteins in its milk); U.S. Patent No. 5,849,992 (Dec. 15, 1998) (patenting a transgenic cow that produces milk containing human antibodies); U.S. Patent No. $5,750,176$ (May 12,1998 ) (patenting transgenic mammals that produce certain human biological compounds in their milk); U.S. Patent No. 5,716,817 (Feb. 10, 1998) (patenting transgenic mammals that produce a human biochemical that has medicinal properties for infants); U.S. Patent No. 5,700,671 (Dec. 23, 1997) (patenting transgenic mammals that produce human oligosaccharides and glycoproteins in their fatty tissues); U.S. Patent No. 5,661,016 (Aug. 26, 1997) (patenting a transgenic animal that produces various heterologous antibodies in its milk): U.S. Patent No. 5,633,425 (May 27, 1997) (patenting a transgenic animal that produces human antibodies in its milk); U.S. Patent No. 5,545,806 (Aug. 13, 1996) (patenting transgenic animals that produce human heterologous antibodies).

113. Before we begin this analysis, there is one limitation that must be made clear: There are no chimeras presently available for evaluation. The applicants, two scientists opposed to the patenting of any life, want the patent so that they may personally control the technology and prevent any other person from using it for ill-conceived ends (at least during the life of the patent). Their moral apprehensions, however, have prevented them from actually engineering such a creature. Thus, there is no organism to which we may refer or evaluate under the evolutionary biology test. See Salkin, supra note 13. 
chimera's natural occurrence is very low. ${ }^{114}$ Again, the genetic and physical differences between humans and other animals prevent such a creature from developing through natural breeding. ${ }^{1 / 5}$ Thus, the first part of the inquiry would be satisfied. However, the potential of the organism's survival remains unclear. Here, the lack of an actual chimera hinders conclusive analysis, but the advantages of evolutionary biology remain unaffected.

Assuming that the chimera could reproduce sexually with one or both of its progenitor species, ${ }^{116}$ then the inquiry would shift to the influence of the creature's new characteristics on its human- and natural-selection rates. A multitude of factors can affect the ratio between these two survival indexes, preventing any definitive conclusion regarding the patentability of such creatures at this time. There are, however, several potential conclusions that we can tentatively draw.

On the one hand, there is a relatively high probability that nature may actually favor a chimera's existence rather than select against it. Animals that have some enhanced intellectual capabilities might maintain a relatively high natural-selection rate, leading to the survival and flourishing of their genotype. In this case, a pig with a human mind would have an advantage over regular pigs. On the other hand, normal pigs might not select for intelligence, making it a disfavored trait and contributing to the chimera pig's demise. As previously discussed, the human pig might also be overly selected, leading to the collapse of the overall species of pig. ${ }^{17}$ When such chimeras are compared to humans, it is equally unclear what difference there would be between the human- and natural-selection rates. Both rates involve human preferences, which could shift the direction of selection.

Despite the uncertainty in knowing the effect that genetic engineering will have on a chimera's selection, it appears likely that there will be some difference between a chimera's selection and that of its progenitor species.

114. The patent application apparently does not describe exactly the organism that would be produced. The application's contents are often discussed in terms of its process and not its product, even though it is the product that has sparked the controversy. Thus, we must refer to the organism in the abstract rather than giving it a specific name or set of characteristics.

115. For example, it is highly unlikely that the chromosomes would match in number and natural pairing. See G. LEDYARD STEBBINS, DARWIN TO DNA. MOLECULES TO HUMANITY $90-98$ (1982). Animal behavior and simple morphology also prevent different species from interbreeding, even if progeny were a genetic possibility. See id. at 91.

116. According to reproductive biology principles, many animals that are a combination of two similar species are unable to reproduce. See id. at 94-98. For example, mules, the offspring of a horse and donkey, are sterile from birth. See id. at 91-92. If this general principle holds true for chimeras, the probability that its morphology would persist beyond one generation is a near impossibility unless human DNA is combined with that of an asexually reproducing animal. Excluding that possibility, such a chimera would likely pass both prongs of the test and be eligible for patent protection. But given that chimeras are transgenic creanures, there is an even greater possibility that they can reproduce inasmuch as such things may be controlled through genetic manipulation.

117. See supra text accompanying notes 107-108. 
The application of evolutionary biology gives policymakers the flexibility to tailor established standards to the demands of various organisms, rather than processing applications through an ad hoc and unpredictable system. Under this regime, the requisite difference between natural- and humanselection rates for chimeras might be higher than that for a transgenic mouse. ${ }^{118}$ The PTO could, in effect, combine its commentary on the morality of patenting human life with the standards of evolutionary biology. This system would establish a limit to the extent to which researchers could harness the power of biotechnology, while still allowing for the development of transgenic organisms that contained human DNA. The end result would be a set of quantifiable scientific standards that could be tempered by human ethics-quite possibly the most responsible and effective means of addressing such powerful technology. ${ }^{119}$

The scientists who filed the chimera patent did so in an attempt to raise awareness of this looming question in patent law and to pressure policymakers into at least developing a set of formal rules regarding the patenting of animals. ${ }^{120}$ The PTO responded with dicta from an outdated common-law case. If we are to maintain a system of animal and plant patents that is both legitimate and efficient, a new analytical paradigm is needed. This new system must use the principles of science to its advantage rather than fear the intricacies of its application. The introduction of evolutionary biology into the patent-application process is a step toward that new paradigm. Although this proposal may not be the perfect answer to all the epistemological questions about the plant- and animal-patent system, it represents a tangible and comparatively advantageous improvement upon the amorphous regime in place today.

118. It should, however, be reasonably calculated, recognizing the possibility that there may be some limited circumstances in which society may benefit from the development of such creatures.

119. Even those who criticize the very notion of patenting life must realize that prohibiting such patents will not stop researchers from developing the technology. Although the potential profits from biotechnology may accelerate the process, there is nothing to prevent a person from creating a chimera. In the absence of patent protection, there is also no way of controlling the proliferation of the technology. Opponents of such patents must ask themselves whether it is the mere thought of owning life that is abhorrent or a more fundamental uncasiness with the technology that is the problem. Attacking patent law addresses the former concem but has little effect on the latter.

120. The chimera concept does not include half-human, half-plant creatures. Thus, it is concerned only with the animal-patent process. 